\title{
PENERAPAN MODEL RECIPROCAL TEACHING DENGAN GAME SMART CASE UNTUK MENINGKATKAN MINAT BELAJAR BIOLOGI DI SMA NEGERI 1 ANGKOLA TIMUR
}

\author{
Elwidani Siregar, Iskandar Safri Hasibuan, Yusni Atifah \\ Pendidikan Biologi, FKIP Universitas Muhammadiyah Tapanuli Selatan \\ yusniatifah@gmail.com
}

\begin{abstract}
The problem in this research is the low interest of student biology in class $\mathrm{X}_{3}$ SMA Negeri 1 Angkola Timur. To overcome this problem, this research applied the learning model of Reciprocal Teaching with Game Smart Case on the subject of the ecosystem in class $\mathrm{X}_{3} \mathrm{SMA}$ Negeri 1 Angkola Timur can increase student biology interest. The research method used is class action research method (PTK) which is implemented in two cycles which each cycle consists of four stages: planning, implementation, observation and reflection. Learning tools in this study are RPP, student interest questionnaire, test instrument sheet and student observation sheet. The results of the study were analyzed descriptively and obtained through the application of Reciprocal Teaching learning model with Game Smart Case can increase the students 'biology interest in class $\mathrm{X}_{3}$ SMA Negeri 1 Angkola Timur, especially the subject of ecosystem, based on the questionnaire of students obtained in cycle I of $65.80 \%$ And in cycle II equal to $81,13 \%$. Based on student learning test in cycle I get completeness equal to $63,33 \%$ and cycle II equal to $83,33 \%$, then based on student activity observation result obtained percentage equal to $62,90 \%$ and at second cycle equal to $80,83 \%$. Based on the results of this study can be concluded that there is increased interest in learning biology of students through the learning model Reciprocal Teaching with Game Smart Case in class $X_{3}$ SMA Negeri 1 Angkola Timur.
\end{abstract}

Keywords:Interest in learning, Reciprocal Teaching model, Game Smart Case.

\begin{abstract}
Abstrak
Masalah dalam penelitian ini adalah rendahnya minat mahasiswa biologi pada kelas X3 SMA Negeri 1 Angkola Timur. Untuk mengatasi masalah ini, penelitian ini mengaplikasikan model pembelajaran Reciprocal Teaching dengan Game Smart Case pada subjek ekosistem di kelas X3 SMA Negeri 1 Angkola Timur dapat meningkatkan minat belajar mahasiswa. Metode penelitian yang digunakan adalah metode penelitian tindakan kelas (PTK) yang diimplementasikan dalam dua siklus dimana masing-masing siklus terdiri dari empat tahap: perencanaan, pelaksanaan, observasi dan refleksi. Alat pembelajaran dalam penelitian ini adalah RPP, kuesioner minat siswa, lembar instrumen uji dan lembar observasi siswa. Hasil penelitian dianalisis secara deskriptif dan diperoleh melalui penerapan model pembelajaran Reciprocal Teaching dengan Game Smart Case yang dapat meningkatkan minat biologi siswa di kelas X3 SMA Negeri 1 Angkola Timur, khususnya subjek ekosistem, berdasarkan kuesioner siswa yang diperoleh pada siklus I $65,80 \%$ dan pada siklus II sebesar $81,13 \%$. Berdasarkan hasil belajar siswa pada siklus I mendapatkan kelengkapan sebesar 63,33\% dan siklus II sebesar $83,33 \%$, maka berdasarkan hasil observasi aktivitas siswa diperoleh persentase sebesar $62,90 \%$ dan pada siklus II sebesar $80,83 \%$. Berdasarkan hasil penelitian ini dapat disimpulkan bahwa ada peningkatan minat belajar biologi siswa melalui model pembelajaran Reciprocal Teaching dengan Game Smart Case pada kelas X3 SMA Negeri 1 Angkola Timur.
\end{abstract}

Kata Kunci: Minat belajar, Model Reciprocal Teaching.Game Smart Case. 


\section{PENDAHULUAN}

Biologi merupakan salah satu cabang ilmu yang memegang peranan penting dalam pengembangan ilmu pengetahuan dan teknologi. Untuk itu pada saat mengikuti pelajaran di kelas, semua siswa diharapkan aktif dalam proses pembelajaran. Dengan demikian siswa akan lebih mudah untuk memahami materi yang disampaikan oleh guru termasuk guru biologi. Dalam serangkaian proses belajar mengajar di kelas, kegiatan belajarmengajar merupakan kegiatan yang penting, itu berarti berhasil atau tidaknya tujuan pencapaian pengajaran di sekolah banyak tergantung pada situasi kegiatan belajar - mengajar yang dilaksanakan di dalam kelas (Daryanto, 2010).

Rendahnya minat belajar biologi sebagian siswa di kelas $\mathrm{X}_{3}$ di SMA Negeri 1 Angkola Timur, bukti ataupun fakta yang diperoleh yaitu dari hasil angket minat siswa terhadap pembelajaran yang dibagikan pada hari selasa 15 Nopember 2016, didapatkan bahwa 30 siswa di kelas $\mathrm{X}_{3}$ di SMA Negeri 1 Angkola Timur di peroleh: 1. Perhatian belajar siswa dari angket yang dibagikan yaitu, kategori cukup ada 11 orang, kategori kurang 10 orang, kategori baik 9 orang. 2. Kemauan belajar siswa dari angket yang dibagikan yaitu, kategori cukup ada 13 orang, kategori kurang 10 orang, kategori baik 7 orang. 3. Kesenangan belajar siswa dari angket yang dibagikan yaitu, kategori cukup ada 9 orang, kategori kurang 15 orang, kategori baik 6 orang. 4. Motif belajar siswa dari angket yang dibagikan yaitu, kategori cukup ada 14 orang, kategori kurang 10 orang, kategori baik 6 orang. Jadi dari hasil angket yang diperoleh di atas maka dapat diketahui bahwa minat belajar siswa di kelas X3 SMA Negeri 1 Angkola Timur masih rendah.

Salah satu penyebab rendahnya hasil belajar siswa adalah rendahnya minat belajar siswa. Setelah penulis mengamati dan telah mengadakan wawancara dengan salah seorang guru biologi di SMA Negeri
1 Angkola Timur, yaitu Ibu Rina Hafijah, S.Pd yang mengajar biologi di kelas $\mathrm{X}_{3}$ menyatakan bahwa masih banyak menemukan kelemahan-kelemahan siswa dalam belajar biologi. Salah satu kelemahan yang dialami siswa adalah kurangnya kemampuan pemecahan masalah biologi yang diberikan oleh guru.

Hal tersebut disebabkan karena kurang tepatnya model pembelajaran yang disajikan oleh guru pada saat mengajar dan model pembelajarannya kurang bervariasi. Dalam proses belajar mengajar guru lebih sering menjelaskan melalui metode ceramah dan tanya jawab. Sehingga siswa cenderung pasif dan aktifitas yang dilakukan siswa hanya mendengarkan, mencatat, dan mengerjakan soal. Siswa masih malu bertanya kepada guru jika mengalami kesulitan dalam memahami atau menyelesaikan soal yang diberikan. Hasil observasi yang dilaksanakan pada tanggal 25 Oktober 2016.

Pembelajaran yang seperti itu jelas didominasi oleh guru dengan menekankan kepada aspek ingatan dan menyampaikan aspek pemahaman, penalaran, komunikasi dan pemecahan masalah. Guru terlihat lebih aktif, sementara siswa bersifat pasif. Keterlibatan siswa dalam proses penemuan pengetahuan sangat rendah. Siswa hanya menunggu dari guru tanpa ada usaha untuk menemukan sendiri pengetahuan, keterampilan, dan sikap yang dibutuhkan.

Untuk meningkatkan minat belajar siswa bisa dilakukan dengan beberapa cara, salah satunya dengan menggunakan model pembelajaran yang tepat. Dari sekian banyak model pembelajaran biologi yang dapat mengaktifkan minat belajar siswa dalam belajar biologi, salah satu diantaranya adalah model pembelajaran Reciprocal Teaching dengan Game Smart Case. Menurut Nur (2000) Menyatakan bahwa dengan Reciprocal Teaching mengajarkan siswa keterampilanketerampilan kognitif penting dengan menciptakan pengalaman belajar, melalui pemodelan perilaku tertentu dan kemudian membantu siswa mengembangkan 
PeTeKa (Jurnal Penelitian Tindakan Kelas dan Pengembangan Pembelajaran)

Vol 1 No 1 Tahun 2017 Hal 34-40

keterampilan tersebut atas usaha mereka sendiri dengan pemberian semangat, dukungan dan suatu sistem scaffolding.

Menurut Trianto (2010) Reciprocal

Teaching merupakan rangkaian kegiatan belajar yang melibatkan secara maksimal seluruh kemampuan siswa untuk mencari, menyelidiki, secara sistematis, kritis, logis analitis, sehingga dapat merumuskan sendiri dari pemahaman bacaan yang dibaca dari materi yang dipelajari dengan penuh percaya diri.

Berdasarkan latar belakang masalah di atas peneliti tertarik untuk melakukan penelitian dengan Judul"Penerapan Model Reciprocal Teaching dengan Game Smart Case Untuk Meningkatkan Minat Belajar Biologi Siswa Di SMA Negeri 1 Angkola Timur Tahun pelajaran 2016-2017”.

\section{METODE}

Jenis penelitian ini adalah penelitian tindakan kelas (Clasroom Action Research). Model pembelajaran yang dilakukan adalah Reciprocal Teaching dengan Game Smart Case karena penelitian ini bertujuan untuk melihat kesulitan yang dialami siswa dalam menyelesaikan soal dan cara untuk meningkatkan minat belajar biologi siswa pada pokok bahasan ekosistem. Dalam siklus PTK dapat dilakukan beberapa tahap kegiatan. Adapun rincian kegiatan pada setiap tahapan adalah sebagai berikut :

(1)Perencanaan adalah persiapan yang dilakukan untuk melaksanakan pembelajaran Model Reciprocal Teaching dengan Game Smart Case. Kegiatan yang dilakukan yaitu:
(a)Menganalisis kurikulum untuk mengetahui kompetensi dasar yang akan disampaikan kepada siswa.
(b)Membuat rencana pelaksanaan pembelajaran Model Reciprocal Teaching dengan Game Smart Case pada materi ekosistem
(c)Membuat rencana Lembar Kerja Siswa

(d)Membuat instrumen yang digunakan dalam siklus PTK

(e) Menyusun alat evaluasi pembelajaran (2)Pelaksanaan

(a) Pelaksanaan, melaksanakan pembelajaran Model Reciprocal Teaching dengan Game Smart Case pada materi ekosistem, guru memberikan tugas meneliti sesuatu masalah tentang materi pelajaran.

(b)Siswa dibagi menjadi beberapa kelompok dengan beranggotakan 6 orang.

(c)Masing-masing kelompok mempelajari dan membahas tugas untuk di diskusikan.

(d)Hasil diskusi kelompok dipersentasikan untuk ditanggapi oleh kelompok yang lain.

(e)Guru memberikan kesimpulan dari hasil diskusi yang telah dilakukan siswa.

(3)Pengamatan (observasi), mengamati seluruh kegiatan dikelas dan perubahan yang terjadi pada saat diberikan tindakan.

(a) Situasi kegiatan belajar mengajar

(b)Keaktifan Siswa

(c)Peningkatan minat belajar siswa

(4)Refleksi

Peneliti melakukan refleksi terhadap pelaksanaan siklus pertama dan menyusun rencana untuk siklus kedua (Arikunto, 2012)

Teknik pengumpulan data dalam penelitian ini adalah angket, tes, dan observasi. Setelah data dari setiap tes dikumpulkan, maka dilaksanakan analisis data dari hasil tes.

a. Analisis data minat belajar siswa

Persentase minat siswa $=$ frekuensi setiap pengamatan

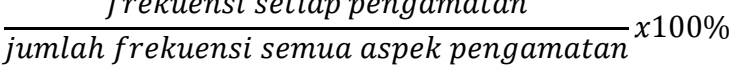

b. Analisis Data Tes Hasil Belajar

$\mathrm{PKK}=\frac{\sum \mathrm{X}}{\mathrm{Y}}$

c. Analisis Observasi Aktivitas Siswa

Persentase Aktivitas Siswa $=$

$\frac{\text { Frekuensi setiap aspek pengamatan }}{\text { mlah frekuensi semua aspek pengamatan }}$ X $100 \%$

(Arikunto, 2009) 


\section{HASIL DAN PEMBAHASAN}

Hasil angket minat siswa pada siklus I dapat dilihat dari jawaban responden dengan menggunakan model pembelajaran Reciprocal Teaching dengan Game Smart Case masih tergolong rendah dengan persentase sebesar $65,80 \%$, artinya siswa masih kurang setuju bahwa belajar biologi itu menyenangkan dan mampu memberikan pengaruh yang sangat baik terhadap peningkatan minat belajar biologi siswa. Untuk mencapai indikator maka peneliti mengambil tindak lanjut pada siklus II diharapkan siswa lebih antusias terhadap belajar biologi.

Untuk hasil belajar siswa pada siklus I masih menunjukkan nilai ketuntasan yang belum memuaskan yaitu $63,33 \%$, sehingga akan dilanjutkan ke siklus II.

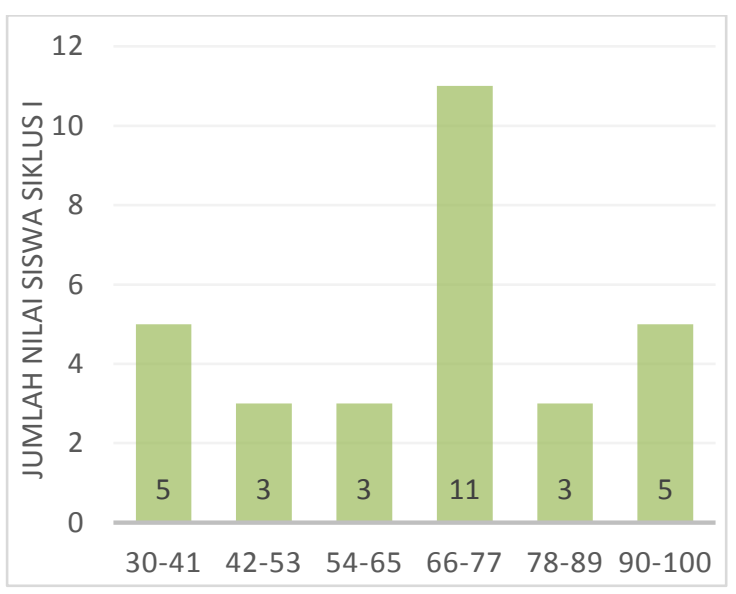

Gambar 1: Grafik Tes Hasil Belajar Siswa Siklus I

Hasil observasi aktivitas siswa siklus I adalah 62,90\% sedangkan untuk kualifikasi nilai adalah cukup. Dari hasil observasi aktivitas belajar siswa siklus I di atas dapat dijelaskan bahwa hasil observasi aktivitas belajar siswa belum sesuai dengan apa yang direncanakan dalam penelitian ini belum memenuhi indikator keberhasilan yang ditetapkan adalah $\geq 75 \%$.

Setelah melakukan penyebaran angket minat siswa pada siklus II ini dengan menggunakan model Reciprocal
Teaching dengan Game Smart Case maka diperoleh persentase sebesar 81,13\%, artinya siswa telah setuju bahwa belajar biologi itu menyenangkan dan mampu memberikan pengaruh yang sangat baik terhadap peningkatan minat belajar biologi siswa. Dimana siswa terlihat aktif serta progresif dalam belajar. Pada siklus II perolehan persentase telah mencapai indikator dan penelitian diberhentikan pada siklus II. Untuk hasil belajar siswa pada tes siklus II yaitu persentase ketuntasan sebesar $83,33 \%$.

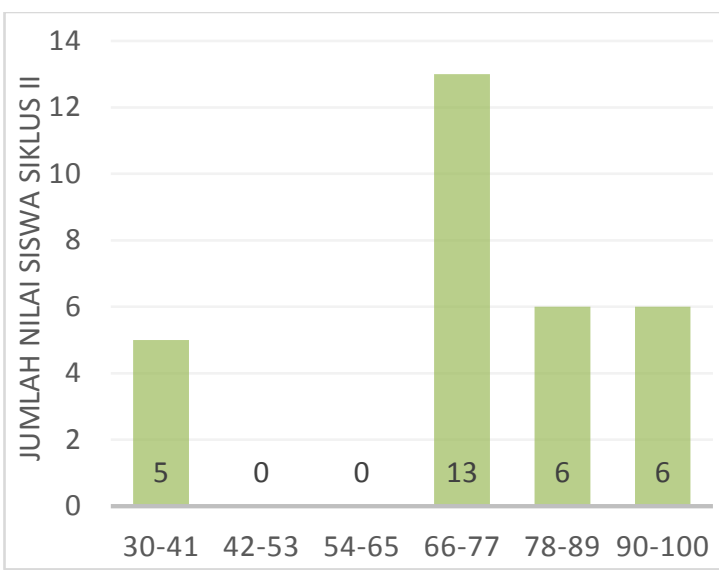

Gambar 2: Grafik Tes Hasil Belajar Siswa Siklus II

Hasil observasi aktivitas siswa siklus II dapat dijelaskan persentase siklus II adalah sebesar 80,83\% sedangkan untuk kualifikasi nilai adalah baik. Dari hasil observasi aktivitas siswa siklus II di atas dapat dijelaskan bahwa hasil observasi siswa telah memenuhi indikator keberhasilan yang direncanakan dalam penelitian ini sebesar $75 \%$ maka penelitian ini tidak perlu dilanjutkan lagi dan berhenti pada siklus II.

Penelitian ini berakhir setelah selesai melaksanakan siklus II, karena pada siklus II telah tercapai indikator keberhasilan yang telah ditetapkan. Pada siklus I, diperoleh persentase minat belajar siswa sebesar $65,80 \%$ dan siklus II sebesar $81,13 \%$. Ini berarti adanya peningkatan minat belajar biologi siswa. 
PeTeKa (Jurnal Penelitian Tindakan Kelas dan Pengembangan Pembelajaran)

Vol 1 No 1 Tahun 2017 Hal 34-40

Berdasarkan persentase minat belajar siswa pada siklus I, guru dan siswa telah melakukan kegiatan pembelajaran yang sesuai dengan model pembelajaran Reciprocal Teaching dengan Game Smart Case namun masih ada kekurangankekurangan. Dimana kekurangankekurangan itu ada yang berasal dari siswa. Diantaranya masih banyak siswa yang tidak paham model pembelajaran Reciprocal Teaching dengan Game Smart Casesehingga siswa kurang serius mengikuti proses pembelajaran.

Melihat kekurangan yang masih ada dan rendahnya minat belajar siswa terhadap pokok bahasan ekosistem. Pada tindakan siklus I belum memenuhi indikator keberhasilan yang telah ditetapkan, maka penelitian dilanjutkan pada siklus II. Setelah siklus II dilaksanakan, persentase minat belajar siswa menunjukkan peningkatan dari $65,80 \%$ menjadi sebesar $81,13 \%$.

Hal ini berarti minat belajar siswa telah mencapai indikator keberhasilan yang telah ditetapkan, karena indikator keberhasilan dalam penelitian telah tercapai. Ini berarti hipotesis tindakan telah tercapai yaitu dengan menggunakan model pembelajaran Reciprocal Teaching dengan Game Smart Case dapat meningkatkan minat belajar siswa pada materi ekosistem. Peningkatan minat belajar siswa disetiap siklus dapat kita lihat pada tabel.

Tabel 1: Peningkatan Angket Minat Siswa Siklus I dan II

\begin{tabular}{llll}
\hline No. & Siklus & Persentase & Peningkatan \\
\hline 1. & I & $65,80 \%$ & $15,33 \%$ \\
2. & II & $81,13 \%$ & \\
\hline
\end{tabular}

Dari tabel diatas maka diagram grafik data tersebut dapat dilihat pada gambar.

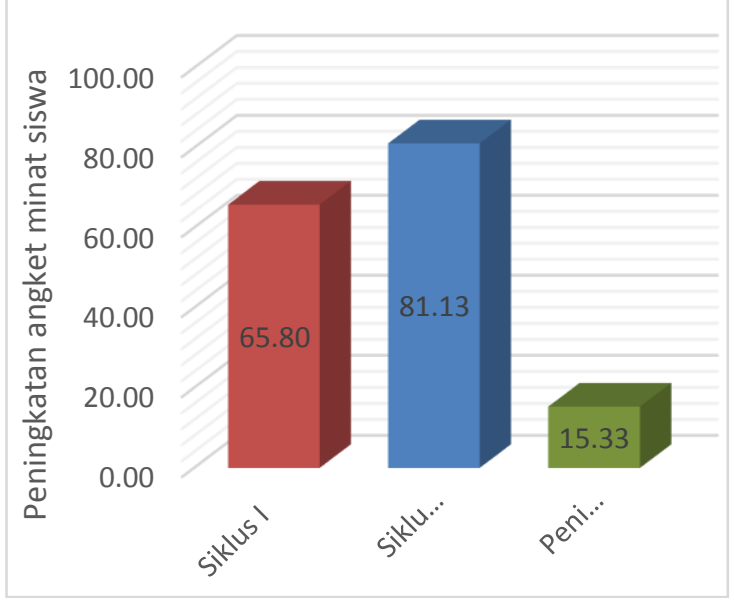

Gambar 3: Grafik Kenaikan Angket Minat Siswa Siklus I dan II

Berdasarkan hasil gambar di atas dapat disimpulkan bahwa guru telah mampu menerapkan model pembelajaran Reciprocal Teaching dengan Game Smart Case pada pokok bahasan ekosistem Di Kelas X3 SMA Negeri 1 Angkola Timur dengan baik sehingga dapat meningkatkan minat belajar siswa dalam belajar biologi.

Meningkatnya minat belajar siswa berakibat pada meningkatnya hasil belajar siswa, yang dapat diukur melalui tes. Hasil tes menunjukkan peningkatan hasil belajar siswa tertera pada Tabel 1 dan Gambar 3.

Tabel 2: Hasil Analisis Tes Belajar Siswa Siklus I dan II

\begin{tabular}{llll}
\hline No. & Siklus & $\begin{array}{l}\text { Rata- } \\
\text { rata }\end{array}$ & $\begin{array}{l}\text { Persentase } \\
\text { Ketuntasan }\end{array}$ \\
\hline 1. & I & 67,90 & $63,33 \%$ \\
2. & II & 73,46 & $83,33 \%$ \\
\hline
\end{tabular}

Dari tabel diatas dapat dilihat persentase peningkatan tes hasil belajar siswa setiap siklusnya. Dimana pada kegiatan siklus I yang diukur melalui tes siklus I jumlah siswa yang tuntas sebanyak 19 orang atau . kemudian setelah dilakukan tindakan pada siklus kedua, jumlah siswa yang tuntas bertambah menjadi 25. Berdasarkan datadata kenaikan diatas tersebut maka kenaikan nilai tes belajar siswa juga dapat dilihat melalui gambar. 


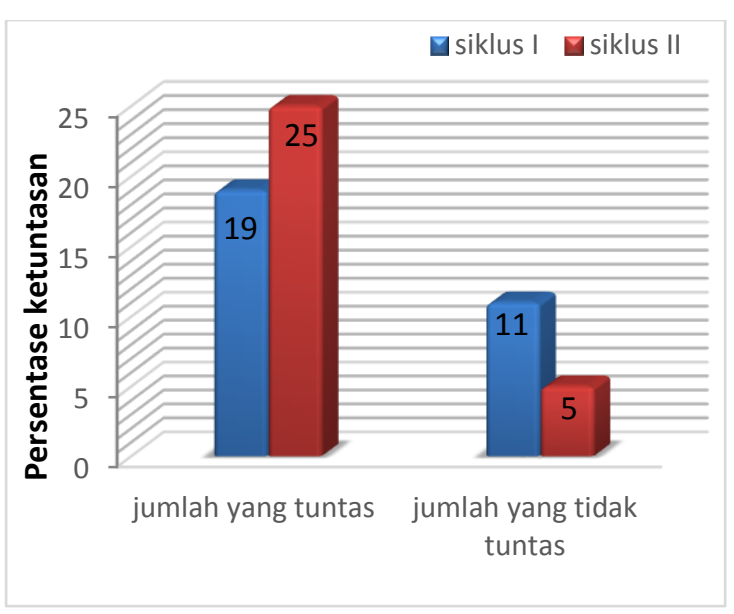

Gambar4: Grafik Peningkatan Tes Hasil Belajar Siklus I dan II

Dalam proses belajar mengajar dengan menerapkan model pembelajaran Reciprocal Teaching dengan Game Smart Case aktivitas belajar siswa menjadi bahan perhatian guru, berdasarkan observasi yang selalu dilakukan pada setiap pertemuannya maka pada siklus I memperoleh persentase 62,90 dan pada siklus II hasilnya lebih meningkat lagi menjadi $81,93 \%$ dan mengalami peningkatan sebbesar $17,93 \%$. Untuk lebih jelas dapat dilihat pada tabel .

Tabel 3:Peningkatan observasi Aktivitas Siswa siklus I dan II

\begin{tabular}{llll}
\hline No. & Siklus & Persentase & Peningkatan \\
\hline 1. & I & $62,90 \%$ & $17,93 \%$ \\
2. & II & $80,83 \%$ & \\
\hline
\end{tabular}

Dari tabel di atas maka diagram grafik data tersebut dapat dilihat pada gambar.

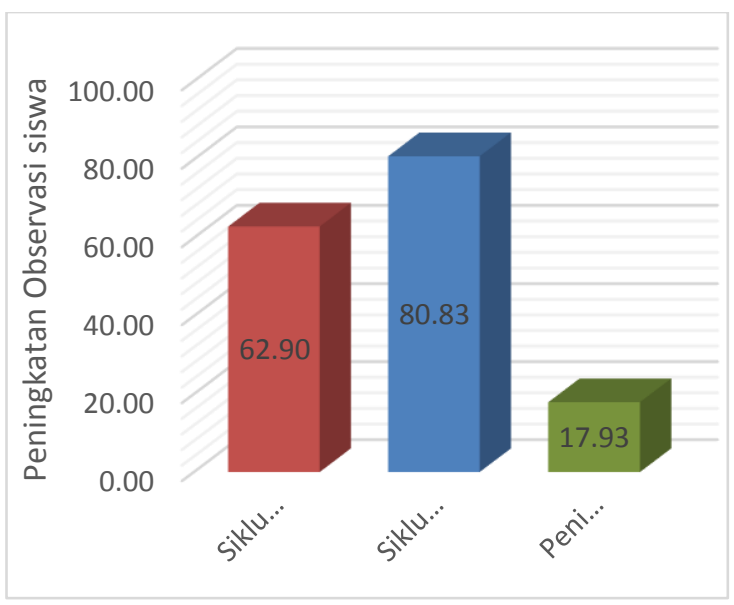

Gambar 5: Grafik Observasi Aktivitas Siswa Siklus I dan II

Adapun hasil dari keseluruhan penelitian dapat dilihat pada tabel dan gambar.

Tabel 4: Hasil Keseluruhan Penelitian Siklus I, dan II

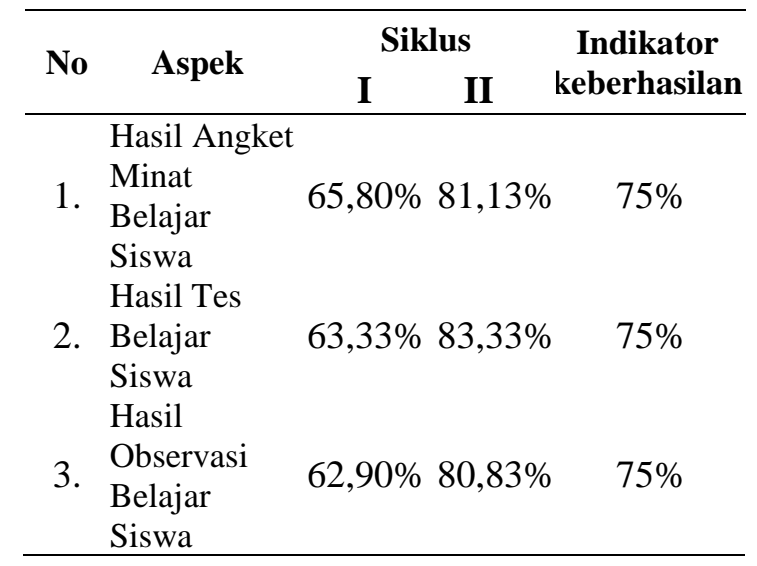

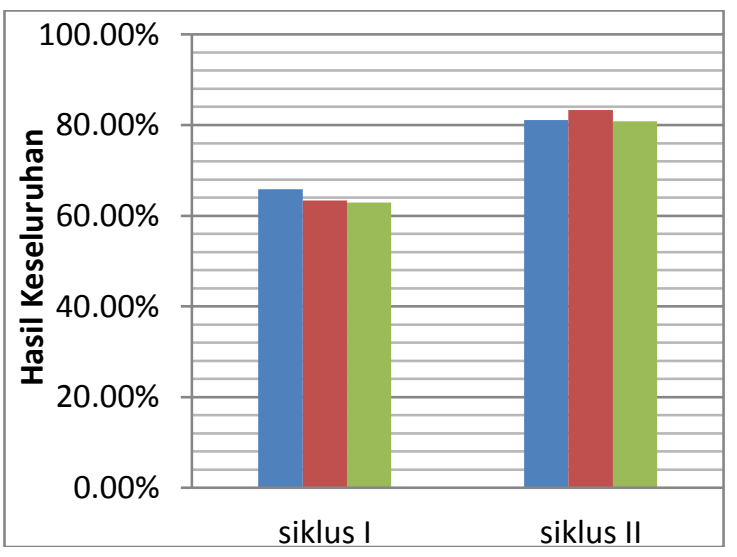

Gambar 6. Grafik Hasil keseluruhan Penelitian Siklus I dan Siklus II 
PeTeKa (Jurnal Penelitian Tindakan Kelas dan Pengembangan Pembelajaran)

Vol 1 No 1 Tahun 2017 Hal 34-40

Berdasarkan hasil keseluruhan yang telah diuraikan dari data-data di atas dapat disimpulkan bahwa minat belajar biologi siswa meningkat di kelas X3 SMA Negeri 1 Angkola Timur melalui penerapan model Pembelajaran Reciprocal Teaching dengan Game Smart Case dan juga hasil belajar siswa serta observasi aktivitas belajar siswa yang dapat dibuktikan minat belajar biologi siswa telah memenuhi indikator yang telah ditetapkan sebesar $75 \%$, hasil belajar siswa juga telah memenuhi indikator yang telah ditetapkan sebesar $75 \%$ dengan KKM 75, observasi aktivitas siswa dalam pembelajaran juga telah memenuhi indikator sebesar $75 \%$.

\section{SIMPULAN}

Berdasarkan hasil penelitian tindakan kelas ini diperoleh kesimpulan sebagai berikut: Peningkatan minat belajar siswa melalui penerapan model pembelajaran Reciprocal Teaching dengan Game Smart Case pada pokok bahasan ekosistem di kelas $\mathrm{X}_{3}$ SMA Negeri 1 Angkola Timur Tahun Pelajaran 20162017, yang dapat dilihat melalui hasil angket siswa pada siklus I dengan persentase sebesar $65,80 \%$ dengan kategori cukup kemudian pada siklus II sebesar $81,13 \%$ dengan kategori sangat baik dari siklus I ke siklus II mengalami peningkatan sebesar $15,33 \%$.

Peningkatan hasil belajar siswa melaui model pembelajaran Reciprocal Teaching dengan Game Smart Case pada pokok bahasan ekosistem di kelas $\mathrm{X}_{3}$ SMA Negeri 1 Angkola Timur Tahun Pelajaran 2016-2017, yang dapat dilihat pada ratarata tes hasil belajar pada siklus I memperoleh rata-rata sebesar 67,90 dengan persentase ketuntasan sebesar 63,33\%, pada siklus II rata-ratanya adalah 73,46 dengan persentase ketuntasan sebesar $83,33 \%$ dari siklus 1 ke siklus II mengalami peningkatan sebesar $20 \%$.
Peningkatan aktivitas belajar siswa melalui penerapan model pembelajaran Reciprocal Teaching dengan Game Smart Case pada pokok bahasan ekosistem di kelas $\mathrm{X}_{3}$ SMA Negeri 1 Angkola Timur Tahun Pelajaran 2016-2017, Yang dapat dilihat melalui hasil observasi siswa pada siklus 1 dengan persentase sebesar $62,90 \%$ dengan kategori cukup kemudian pada siklus II sebesar 80,83\% dengan kategori baik dari siklus 1 ke siklus II mengalami peningkatan sebesar $17,93 \%$.

\section{DAFTAR PUSTAKA}

Arikunto, Suharsimi. (2009). Manajemen Penelitian. Jakarta: PT. Rineka Cipta. . (2012). Penelitian

Tindakan Kelas. Edisi Ke- 11. PT.Bumi Aksara: Jakarta.

Daryanto, (2010). Belajar dan Mengajar, Bandung. CV.Yrama Widya.

Nur, M (2000). Pengajaran Berpusat Kepada Siswa dan Pendekatan Kontruktivis dalam Pengajaran. PPS.Universitas Negeri Surabaya.

Trianto, (2009). Mendesain Model Pembelajaran Inovatif-Progresif. Jakarta: PT. Kencana Persada Media Group. 